\title{
A Guide for Graduate Students Interested in Postdoctoral Positions in Biology Education Research
}

\author{
Melissa L. Aikens, ${ }^{\dagger \$ *}$ Lisa A. Corwin, ${ }^{\dagger \mid}$ Tessa C. Andrews, ${ }^{\neq \mp ~ B r i a n ~ A . ~ C o u c h, ~}{ }^{\neq \#}$

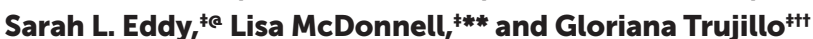 \\ \$Department of Biological Sciences, University of New Hampshire, Durham, NH 03824; \\ "Department of Ecology and Evolution, University of Colorado, Boulder, CO 80309; 'Department \\ of Genetics, University of Georgia, Athens, GA 30602; "School of Biological Sciences, University of \\ Nebraska, Lincoln, NE 68588; 'Department of Biology, Florida International University, Miami, FL \\ 33199; **Division of Biological Sciences, University of California, San Diego, La Jolla, CA 92093; \\ "Office of the Vice Provost for Teaching and Learning, Stanford University, Stanford, CA 94305
}

\begin{abstract}
Postdoctoral positions in biology education research (BER) are becoming increasingly common as the field grows. However, many life science graduate students are unaware of these positions or do not understand what these positions entail or the careers with which they align. In this essay, we use a backward-design approach to inform life science graduate students of postdoctoral opportunities in BER. Beginning with the end in mind, we first discuss the types of careers to which BER postdoctoral positions lead. We then discuss the different types of BER postdoctoral positions, drawing on our own experiences and those of faculty mentors. Finally, we discuss activities in which life science graduate students can engage that will help them gauge whether BER aligns with their research interests and develop skills to be competitive for BER postdoctoral positions.
\end{abstract}

\section{INTRODUCTION}

Postdoctoral positions are often a necessary training experience for those who graduate with a doctorate in the life sciences and are interested in pursuing an academic career. Among postdoctoral job announcements, there are an increasing number and diversity of positions related to biology education. The titles of these postdoctoral positions vary, but include "postdoctoral researcher in biology education," "postdoctoral teaching and learning scholar," "postdoctoral fellow in biology education research and teaching," "education fellow," and "teaching postdoctoral associate." Graduate students interested in teaching and student learning often find these opportunities appealing. Yet the diversity of positions available can be confusing to people new to the field. In addition, applicants may not realize how different positions provide training for different career paths. In this paper, we outline the different types of postdoctoral positions involving biology education and describe how each type of postdoctoral position can provide preparation for different careers. We begin by distinguishing two distinct branches of education-related postdoctoral positions in biology, "biology teaching postdoctoral positions" and "biology education research (BER) postdoctoral positions," and go on to explore BER positions in greater depth.

\section{TEACHING VERSUS EDUCATION RESEARCH POSTDOCTORAL POSITIONS}

In a biology teaching postdoctoral position, postdocs spend a significant amount of time (25-100\%) developing and teaching undergraduate biology courses. The remainder of their time is devoted to conducting biology research under the mentorship of a faculty advisor (Kreeger, 2002; Price, 2012). For example, postdocs in the National
Diane K. O'Dowd, Monitoring Editor Submitted March 22, 2016; Revised June 21, 2016; Accepted June 27, 2016

CBE Life Sci Educ December 1, 2016 15:es10 DOI:10.1187/cbe.16-03-0130

'These authors contributed equally to this work as co-first authors.

†These authors contributed equally to this work. *Address correspondence to: Melissa L. Aikens (melissa.aikens@unh.edu).

(c) 2016 M. L. Aikens, L. A. Corwin, et al. CBE-Life Sciences Education () 2016 The American Society for Cell Biology. This article is distributed by The American Society for Cell Biology under license from the author(s). It is available to the public under an Attribution-Noncommercial-Share Alike 3.0 Unported Creative Commons License (http://creativecommons.org/licenses/ by-nc-sa/3.0).

"ASCB®" and "The American Society for Cell Biology $® "$ are registered trademarks of The American Society for Cell Biology. 
Institutes of Health-National Institute of General Medical Sciences' Institutional Research and Academic Career Development Awards (NIH-NIGMS IRACDA) program spend $25 \%$ of their time participating in teaching workshops, observing classes, and preparing for and teaching their own courses. The remaining $75 \%$ of their time entails developing a research program in biology. Teaching postdocs may be hired into positions as tenure-track biology professors at 4-year institutions where they are expected to teach and maintain a biology research program (see Guinnee, 2006, for a view on the merits of the teaching postdoctoral position for a tenure-track faculty career). In some cases, faculty in these positions are also expected to assist with curriculum development or promote pedagogical change. Broadly speaking, teaching postdoctoral positions seek to prepare postdocs for a career in which the central focus is undergraduate teaching (Lemons, 2001; Guinnee, 2006), but they often do not provide specific training to perform education research.

Alternatively, in a BER postdoctoral position, postdocs spend a significant portion of their time conducting research in biology education. Moreover, teaching courses is not necessarily an expectation in these positions. BER postdoctoral positions are part of the emerging field of discipline-based education research (DBER). DBER is geared toward understanding teaching and learning within a scientific discipline and requires a high level of expertise in that discipline (Singer et al., 2012). Many biology DBER scholars hold a doctorate in a biological discipline and have acquired some formal training in education research. BER postdoctoral positions represent one such way that individuals can obtain training in this field. BER graduate programs represent an additional means of acquiring the biological and educational training needed to pursue DBER careers, but these programs will not be discussed in this essay. BER postdoctoral positions are relatively new opportunities, and many life science graduate students may not be aware of or understand these positions. As such, this essay aims to characterize these positions and discuss careers to which they can lead in order to inform life science graduate students' next steps in their academic careers.

We draw on our own postdoc experiences in BER, as well as on interviews of faculty mentors who regularly hire and employ BER postdocs, to inform this essay. Using backward-design principles, which begin with the end in mind (Wiggins and McTighe, 2005), we first describe 1) the types of careers for which these positions provide training and 2) the array of opportunities and responsibilities encompassed by different BER postdoctoral positions that can lead to these careers. We go on to provide advice to help graduate students 3) determine whether a BER postdoctoral position is the right career choice for them and 4) gain skills and experience to be competitive for such a position. Our postdoc experiences are varied, reflecting the diversity of postdoctoral opportunities available within the biology education community. Therefore, this work is intended to provide a broad overview of the postdoctoral opportunities available in the field of BER for recent life science graduates with doctoral degrees.

\section{What Careers Does BER Postdoctoral Work Lead To?}

Ultimately, deciding whether to pursue a postdoctoral position in BER depends on career goals. In general, BER postdocs are positioned for jobs that entail either education research or program evaluation and involve either teaching or supporting others' teaching endeavors. In Figure 1 we present our own personal perspectives on the different positions we took after completing BER postdoctoral positions. However, our jobs are a limited sample of the positions that BER postdocs might pursue. For example, BER postdocs may want to pursue positions as biology lecturers. While some biology lecturers teach exclusively, others may have additional responsibilities, including performing course assessment, training other faculty in pedagogy, or designing curricula. Indeed, some biology lecturers may even be expected to perform DBER, much like the teaching professor position described in Figure 1. Because lecturer positions have such a diverse range of responsibilities, it is a good idea to research these positions extensively before applying. Additionally, some BER postdocs would be qualified for jobs in program evaluation. These positions are growing in number due to the requirement by many funding agencies that programs gather evidence of their efficacy and merit. Program evaluation is distinct from research in that it focuses on whether a program is working (evaluation) instead of characterizing how and why it works (research). Postdocs interested in aiding the translation of research to practice and improving existing educational programs may find evaluation positions rewarding.

We have also reviewed and summarized multiple job descriptions for the positions most commonly sought by BER postdocs (Table 1). While this list is not comprehensive, it provides an overview of the central responsibilities and essential skills associated with each position. Although a few BER postdocs have obtained positions as faculty members at primarily undergraduate institutions (PUIs), we did not include details about these positions. While the philosophy of BER postdoctoral positions aligns well with the culture of teaching and learning at PUIs, most of these colleges seek candidates who will conduct research in biology, not biology education. Thus, training in biology research and experience teaching (e.g., via a biology teaching postdoctoral position) may be more suited for these types of positions.

Up-to-date knowledge of current career options and the training needed to obtain them will prove essential for the next generation of biology education researchers in pursuing appropriate postdoctoral positions. We have included a table listing websites that commonly post education-related positions in higher education to provide a continuously updated resource for these jobs (Table 2). In addition, websites of scientific societies (e.g., Ecological Society of America) and discipline-based listservs (e.g., ECOLOG) often post positions related to specific subdisciplines of biology (e.g., ecology lecturer). These resources can be used to outline long-term career goals and align these goals with the BER postdoctoral position that will provide appropriate training.

\section{What Do BER Postdoctoral Positions Entail?}

All BER postdoctoral positions involve conducting research on the teaching and learning of biology. Broadly speaking, biology education researchers study how students gain understanding of biological concepts and the culture (i.e., practices and ways of knowing) of biology, how students develop expertise in biological disciplines, what teaching practices promote learning, what factors influence instructors' teaching 


\section{The Authors' Perspectives}

Gloriana Trujillo; Faculty Development Professional for STEM. Although the term "faculty" is included in this position title, the responsibilities include supporting the entire community of STEM instructors, which includes graduate students, along with lecturers and temure-track faculty. The majority of my time is to instructors about their teaching, and consulting with instructors regarding course design or other pedagogical questions. Various stakeholders around campus also request my expertise in convening committees around curricular decisions and strategic initiatives. Outside of these activities, I stay current with STEM education research on teaching and learning to better inform my daily work.

Lisa McDonnell; Assistant Teaching Professor. In this position I have three main responsibilities and goals: (1) teaching undergraduate classes and laboratory courses, and designing or modifying courses when necessary, (2) conducting biology

education research, and (3) contributing to the department and university community by engaging in teaching-related and administrative service duties (e.g., committee work). I also mentor undergraduate students working with me on BER projects. In a typical week I spend time preparing class material, teaching in class and lab, planning and leading meetings for teams of instructors and graduate student teaching assistants (for large, multi-section courses), attending and/or delivering research participating in or leading workshops for our localSTEM community of practice, and writing up results from BER projects with the aim of publication.

Sarah Eddy; Research Analyst. In this position I am responsible for informing the college about how well it is meeting the educational needs of its students and helping to develop and test interventions to improve the retention and success of students. My day-to-day duties primarily involve analyzing data, designing experiments, managing student research assistants, and reading about relevant educational interventions and statistical methods. My weeks include planning meetings with stakeholders (deans, faculty, directors of student support programs), consultations with instructors either currently running or hoping to run interventions consultations with instructors either currently running or hoping to run interventions in their classrooms, and occasionally leading faculty development workshops. Many of the projects I work on will become publications.

Lisa Corwin; Program Coordinator in Undergraduate Retention. My primary responsibilities include: (1) designing, implementing and evaluating student programs, such as workshops and orientations, to support the academic success of underrepresented student groups in STEM, (2) collaborating with departments and offices across campus to tailor academic support services for these groups, and (3) consulting with faculty and staff across campus and among other local institutions to guide new efforts in student retention in STEM fields. A typical week involves conducting academic success consultations with students, meeting with faculty and staff to engage in new program development, and designing and presenting workshops for students and faculty. I also have opportunities to collaborate on research that aims to characterize students' academic experiences and test the efficacy of new academic interventions.

Melissa Aikens, Tessa Andrews, \& Brian Couch; Assistant Professors. We are tenure-track discipline-based education researchers within science departments at large research universities. Our primary responsibilities include: (1) building and maintaining an externally-funded research program in biology education, which includes designing research studies, collecting and analyzing data, publishing results, and writing grants to secure funding, (2) teaching undergraduate biology courses, (3) mentoring undergraduates, graduate students, and postdocs in biology education research, and (4) engaging in department, university, and professional service activities, such as serving on committees or review panels and advising undergraduates. During a typical week, we coordinate ongoing research, meet with members of the research group or other collaborators, spend time working on variou writing projects (e.g., manuscripts, grants, IRB protocols), teach classes, and attend departmental seminar

FIGURE 1. Five vignettes to illustrate the different positions that the authors have pursued and what these jobs involve. Authors' titles refer specifically to the job and the level at which they were hired, as this best reflects the positions BER postdocs might pursue.

decisions, and how instructors can be inclusive and address the learning needs of all students (Singer et al., 2012). Research questions can be broad, overarching questions that aim to inform the field of BER as a whole, or narrow questions that address the effectiveness of specific educational innovations in a single classroom or for specific topic areas. Some examples of BER include identification of the types of mentoring support that lead to positive outcomes for undergraduate researchers, including women and groups traditionally underrepresented in science, technology, engineering, and mathematics (STEM; Thiry and Laursen, 2011), whether a flipped classroom results in greater student learning and more positive attitudes than an active-learning classroom (Jensen et al., 2015), the effects of jargon on student learning (McDonnell et al., 2016), and whether students experience gains in critical thinking after using the CREATE method to analyze journal articles from the primary literature (Hoskins et al., 2007). Research can also include the development of measurement tools, such as rubrics (e.g., Dasgupta et al., 2014), surveys (e.g., Glynn et al., 2011; Hanauer and Dolan, 2014), concept inventories (e.g., Anderson et al., 2002; Price et al., 2014; Couch et al., 2015), or observation protocols (e.g., Smith et al., 2013; Eddy et al., 2015), for use by the biology education community. For more information on what DBER entails, including broad research topics encompassed by DBER, see the National Academy of Sciences (NAS) report by Singer and colleagues (2012). Table 3 lists other resources that provide an orientation to science education research. These resources address topics such as education research methods, study design, educational assessment, and how to get started in DBER.

The research questions that BER postdocs address depend on the specific postdoctoral position. Many BER postdocs are funded through an advisor's research grant and, therefore, spend most research time working on projects related to the grant. These projects, funded by agencies such as the National Science Foundation (NSF), Howard Hughes Medical Institute (HHMI), or NIH, generally aim to develop a tool or answer a broad question that is relevant to the larger biology education community. For example, one author of this paper (L.A.C.), as part of an NSF grant, characterized several pedagogical elements of course-based undergraduate research experiences in biology and developed a tool to measure the presence of these elements in laboratory courses (Corwin et al., 2015). Other BER postdocs are hired through education initiatives, whereby their research aims to examine the effectiveness of within-course or within-department pedagogical changes. Another author (L.M.) helped instructors transform their courses to use evidence-based teaching practices and conducted research on the effects of the changes in each course. While this type of research aims to inform a specific instructor or institution about the effectiveness of a particular learning environment, the results are often of interest to the larger BER community. Regardless of the projects for which postdocs are hired, most have the opportunity to explore their own interests and develop their own BER research agenda, which is instrumental for those applying to faculty positions.

The percentage of work time that postdocs are expected to dedicate to research varies among BER postdoctoral positions. Some positions are heavily research based, focused primarily on grant writing, conducting research, and publishing manuscripts, much like a traditional biology postdoctoral position. Others include teaching as a component. In 
TABLE 1. Description of positions commonly pursued by BER postdocs

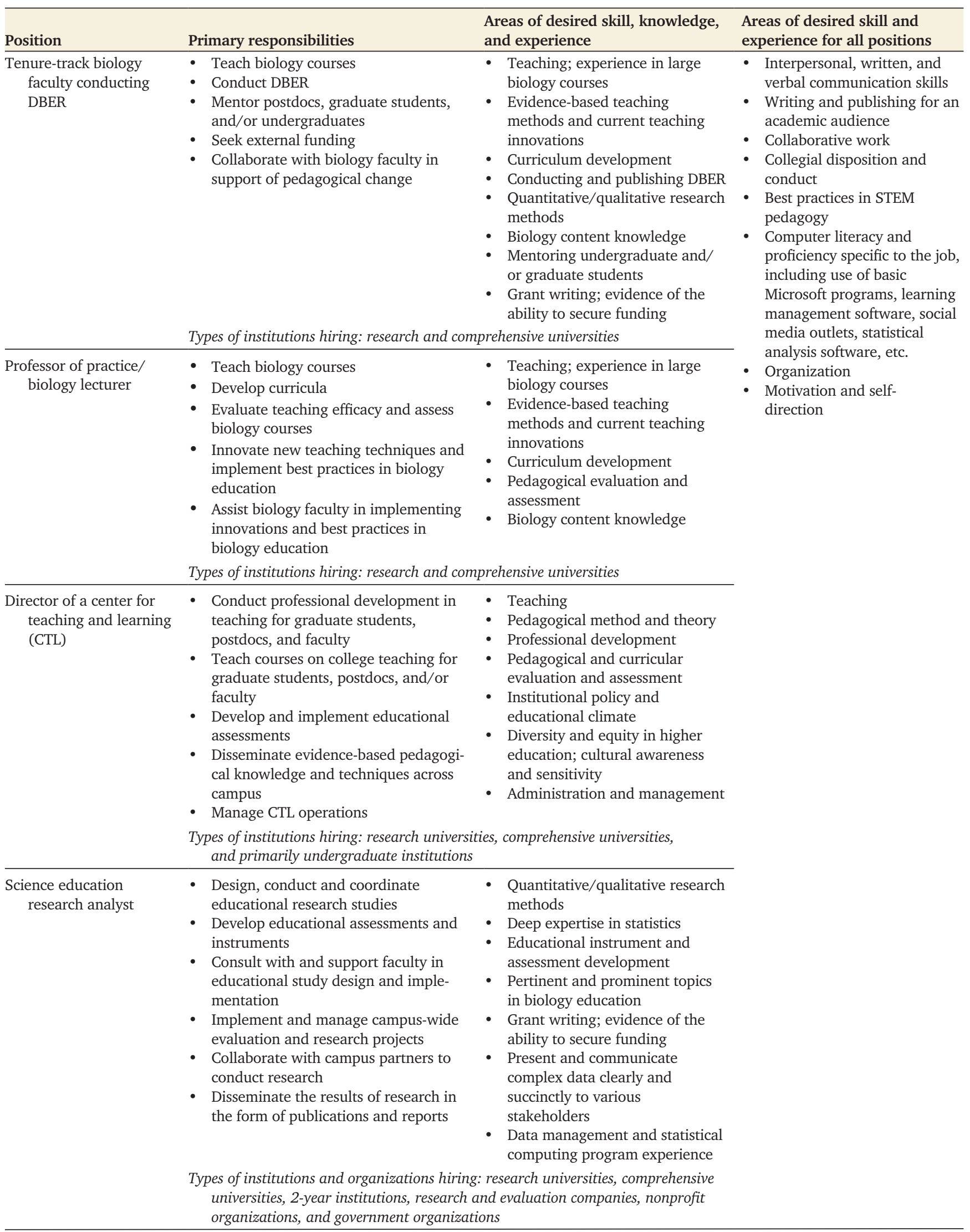


TABLE 1. Continued

\begin{tabular}{|c|c|c|c|}
\hline Position & Primary responsibilities & $\begin{array}{l}\text { Areas of desired skill, knowledge, } \\
\text { and experience }\end{array}$ & $\begin{array}{l}\text { Areas of desired skill and } \\
\text { experience for all positions }\end{array}$ \\
\hline \multirow[t]{2}{*}{$\begin{array}{l}\text { STEM education program } \\
\text { coordinator/director }\end{array}$} & $\begin{array}{l}\text { Develop and manage the educational, } \\
\text { administrative, and logistical activities } \\
\text { of the educational program } \\
\text { - Supervise employees associated with } \\
\text { the program } \\
\text { - Develop and maintain collaborative } \\
\text { relationships across campus } \\
\text { - Assist with program evaluation } \\
\text { - Report on the efficacy and results of the } \\
\text { program }\end{array}$ & $\begin{array}{l}\text { - } \text { Best practices in higher } \\
\text { education program } \\
\text { implementation } \\
\text { - Educational program evaluation } \\
\text { and assessment } \\
\text { - Best practices in supporting } \\
\text { student success through } \\
\text { teaching, mentoring, or advising } \\
\text { - Diversity and equity in higher } \\
\text { education; cultural awareness } \\
\text { and sensitivity }\end{array}$ & \\
\hline & \multicolumn{3}{|c|}{$\begin{array}{l}\text { Types of institutions hiring: research universities, comprehensive universities, and } \\
\text { primarily undergraduate institutions }\end{array}$} \\
\hline
\end{tabular}

Descriptions are based on 10-13 job ads per position posted within the last year on the websites listed in Table 2. Common themes are based on their presence in $70 \%$ or more of job ads. Types of institutions hiring is based on institutions hiring within this sample of job ads.

some cases, this involves partnering with a faculty member to transform a course into one that uses evidence-based methods. This type of position requires developing a curriculum rooted in evidence-based practices, implementing it in the classroom, collecting data to demonstrate effectiveness, discussing the data with other instructional personnel, and using these data to inform future pedagogical decisions. In other postdoctoral positions, the postdoc teaches a course under the mentorship of an experienced faculty member or coteaches a course with a faculty member or another postdoctoral researcher. Of the seven authors, four were expected to teach or coteach at least one course during their postdoctoral experiences, while the other three were expected to engage almost exclusively in research.

BER postdoctoral positions may also involve the management of programs designed to support the professional development of specific groups of biology instructors. These groups may include future high school teachers, graduate teaching assistants, other postdoctoral scholars, or faculty at various institutions. For example, one author (G.T.) worked to develop and manage a program funded by HHMI that engaged biology faculty in pedagogical workshops and continued to provide them with support and resources as they improved their teaching (www.sfsusepal.org/programs/hhmi-biology-fest). She also contributed to the management of a community science education resource center where instructors from local schools could borrow materials for teaching. Another author (L.M.) worked with a science education initiative that aimed to support instructors working on large, service biology courses. In this role, she implemented evidence-based teaching practices, updated curricula, and collected data on student outcomes (www.cwsei.ubc.ca/departments/lifesciences.htm). Other BER postdocs have been involved in the management of programs aimed at enhancing scholarly teaching at community colleges (www.sfsusepal.org/programs/ccb-fest) or providing professional development to faculty interested in implementing quantitative activities in their biology courses (https://qubeshub .org). Much like positions that require curriculum development, these postdoc jobs often include responsibility for evaluation of the program, which is then used to inform future directions.

TABLE 2. Websites of organizations that post education-related positions

\begin{tabular}{ll}
\hline Organization & Job-posting website \\
\hline American Educational Research Association & careers.aera.net/home/index.cfm?site_id=557 \\
$\begin{array}{l}\text { Association for Biology Laboratory Education } \\
\text { Association for Science Teacher Education }\end{array}$ & www.ableweb.org/current-job-opportunities/ \\
$\begin{array}{l}\text { Chronicle of Higher Education } \\
\text { Council on Undergraduate Research listserv }\end{array}$ & https://chroniclevitae.com/job_search/new \\
HigherEdJobs & www.cur.org/resources/instructions_for_cur_listserv \\
National Association for Research in Science Teaching listserv & www.higheredjobs.com \\
Professional and Organizational Development Network open discussion group & www.narst.org/listserv/index.cfm \\
$\begin{array}{l}\text { Science careers: American Association for the Advancement of Science } \\
\text { Society for the Advancement of Biology Education Research }\end{array}$ & http://podnetwork.org/open-discussion-group/ \\
\hline For websites requiring a search, we recommend the following terms: "biology education research," "center for teaching and learning," "education evaluation," "biology \\
lecturer," "science education specialist," "science education research analyst," "faculty development," or "program coordinator STEM."
\end{tabular}


TABLE 3. Resources on the principles and practices of science education research

\begin{tabular}{|c|c|c|}
\hline Title & Authors (year) & Description \\
\hline $\begin{array}{l}\text { How People Learn: Brain, Mind, Experience, } \\
\text { and School, expanded edition }\end{array}$ & $\begin{array}{l}\text { National Research Council } \\
\quad(2000)\end{array}$ & $\begin{array}{l}\text { NAS report that reviews and summarizes the research on how } \\
\text { people learn from the field of cognitive science and links it to } \\
\text { classroom practices. }\end{array}$ \\
\hline $\begin{array}{l}\text { Educational Research: Planning, Conducting } \\
\text { and Evaluating Quantitative and } \\
\text { Qualitative Research }\end{array}$ & J. W. Creswell (2014) & $\begin{array}{l}\text { A text that introduces the practices and procedures of educational } \\
\text { research. It details quantitative methods, qualitative methods, } \\
\text { and mixed-methods approaches to education research. }\end{array}$ \\
\hline $\begin{array}{c}\text { Knowing What Students Know: The Science } \\
\text { and Design of Educational Assessment }\end{array}$ & $\begin{array}{l}\text { J. W. Pellegrino, N. } \\
\text { Chudowsky, and R. Glaser } \\
\text { (2001) }\end{array}$ & $\begin{array}{l}\text { NAS report that examines educational assessment, how the } \\
\text { underlying methodology and philosophy of assessment shapes } \\
\text { education, and how educational assessment can be improved. }\end{array}$ \\
\hline $\begin{array}{l}\text { Estimating Causal Effects Using } \\
\text { Experimental and Observational } \\
\text { Designs }\end{array}$ & $\begin{array}{l}\text { B. Schneider, M. Carnoy, J. } \\
\text { Kilpatrick, W. H. Schmidt, } \\
\text { and R. J. Shavelson (2007) }\end{array}$ & $\begin{array}{l}\text { A report that highlights the strengths and weaknesses of various } \\
\text { study designs and outlines criteria for designing studies that are } \\
\text { appropriate to investigate causal relationships. }\end{array}$ \\
\hline Scientific Research in Education & $\begin{array}{l}\text { R. J. Shavelson and L. Towne } \\
\text { (2002) }\end{array}$ & $\begin{array}{l}\text { NAS report that presents guiding principles and recommendations for } \\
\text { conducting high-quality science education studies based on a } \\
\text { review and synthesis of the literature on science education } \\
\text { research. }\end{array}$ \\
\hline $\begin{array}{l}\text { Discipline-Based Education Research: } \\
\text { Understanding and Improving Learning } \\
\text { in Undergraduate Science and } \\
\text { Engineering }\end{array}$ & $\begin{array}{l}\text { S. R. Singer, N. R. Nielsen, } \\
\text { and H. A. Schweingruber } \\
\text { (2012) }\end{array}$ & $\begin{array}{l}\text { NAS report that synthesizes research on undergraduate teaching } \\
\text { and learning in the sciences, examines the extent to which this } \\
\text { research is translated into practice, and presents resources and } \\
\text { suggestions to further develop DBER. }\end{array}$ \\
\hline $\begin{array}{l}\text { Discipline-Based Education Research: } \\
\quad \text { A Guide for Scientists }\end{array}$ & $\begin{array}{l}\text { S. J. Slater, T. F. Slater, I. } \\
\text { Heyer, and J. M. Bailey } \\
\text { (2015) }\end{array}$ & $\begin{array}{l}\text { A guide for scientists that presents how DBER is done and how to } \\
\text { enter the field. It contains practical tips for starting studies for } \\
\text { both first-time and experienced researchers. }\end{array}$ \\
\hline $\begin{array}{l}\text { Enhancing Scholarly Work on } \\
\text { Teaching and Learning: } \\
\text { Professional Literature That } \\
\text { Makes a Difference }\end{array}$ & M. Weimer (2006) & $\begin{array}{l}\text { A review of scholarly work on teaching and learning for practi- } \\
\text { tioners in the field, including descriptions of exemplary studies. } \\
\text { This book also provides advice for practitioners who would like } \\
\text { to become more involved in research on teaching and learning. }\end{array}$ \\
\hline
\end{tabular}

\section{Deciding Whether a BER Postdoctoral Position Is the Right Career Move}

Many people are initially interested in BER postdoctoral positions because they have a strong interest in teaching. However, it is important to recognize that all BER postdoctoral positions involve a research component, and in many cases, the majority of time will be spent doing research. Many of us found that our initial interest in teaching sparked deep curiosity about how learning in biology happens, how to best instruct or mentor young biologists, or how people become experts in biology. Thus, after completing our doctoral degrees, we found that education research, rather than biology research, more closely aligned with our passions and career goals. Because education research is not a traditional part of a life science doctoral program, graduate students will need to seek out opportunities to help decide whether education research is of interest. We recommend the following for interested graduate students.

1. Conduct a small education research project or collect assessment data for a class. Firsthand participation in education research is the most reliable way to gauge interest in it. Small projects could be conducted in collaboration with discipline-based education researchers at a student's university (in biology, chemistry, physics, engineering, etc.) or with faculty from a college of education. If these options are not available, graduate students can collect assessment data for a course that they teach or assist with. The goal of classroom assessment is to provide an evidence-based approach to improve one's own teaching (Angelo and Cross, 1993; Tanner and Allen, 2004). These projects start by defining what the instructor would like to understand about students' learning. Once articulated, these questions help instructors determine the kind of evidence and data needed to answer each question. In some cases, published rubrics or concept inventories may be appropriate for collecting evidence (D'Avanzo, 2008, and Knight, 2010, provide reviews of biology concept inventories; lists of assessments and other instruments are available at https://go.sdsu.edu/dus/ctl/cabs .aspx; and www.asbmb.org/education/teachingstrategies/ conceptinventory). In other cases, development of new assessments is required to gather the appropriate data (Adams and Wieman, 2011). For example, if an instructor is interested in whether a curriculum component increases students' knowledge about natural selection, the Conceptual Inventory of Natural Selection (Anderson et al., 2002) may be appropriate to use as a pre- and posttest (e.g., Kalinowski et al., 2013). However, if $\mathrm{s} / \mathrm{he}$ is interested in determining what students find most confusing when learning about evolution, asking students to write down the "muddiest point" (Angelo and Cross, 1993) on an index card after each class on evolution may be a good way to collect data. Although classroom assessment does not often provide publishable data, it provides an introduction to thinking about education questions and collecting education data. For a more thorough discussion of how to collect course assessment data, see Tanner and Allen's (2004) paper on collecting evidence in science teaching. 
2. Attend lab meetings of a BER group or attend a biology education conference. Lab meetings and conferences provide opportunities to engage in discourse about education research questions and methodologies with other members of the discipline-based education community and provide an introduction to DBER culture. They also provide opportunities to make connections to people in the DBER community, which can be advantageous for finding and obtaining jobs. Lab meetings can provide a good sense of the day-to-day activities of BER postdocs. They are an inexpensive way to connect to the DBER community, as they can often be attended remotely via conferencing software. Alternatively, conferences provide opportunities to view and explore the diversity of BER while also building a professional network. The Society for the Advancement of Biology Education Research (SABER) holds an annual conference in July (https://saber-biologyeducationresearch.wikispaces.com). The participants are diverse, ranging from distinguished scholars in BER to newcomers who have become interested in BER through their own teaching. The National Association for Research in Science Teaching (NARST) also holds an annual conference (http://narst.org/index.cfm). This large conference, held every April, is a venue for education research aimed at understanding learning and teaching in the various science disciplines at all levels (K-16). A number of science education conferences focus on teaching practices but also contain education research talks. These include the Transforming Undergraduate STEM Education conference sponsored by the American Association of Colleges and Universities (www.aacu.org), the American Society for Microbiology Conference for Undergraduate Educators (www.asmcue.org), the Annual American Biology Laboratory Educators conference (www.ableweb.org); the annual meeting of the Association of College and University Biology Educators (www.acube.org), and the National Association for Biology Teachers Professional Development conference (www.nabt.org), which regularly includes a BER symposium. If it is not possible to attend an education research conference, the annual meetings of many professional societies, such as the Ecological Society of America and the American Society for Cell Biology, organize oral and poster sessions that contain education research.

3. Read biology education journal articles. Reading broadly within the field allows exploration of the breadth of questions, methodologies, and objectives in BER. Descriptive essays provide a synopsis of the different views, priorities, and directions of investigation within areas of general interest. "Practice" articles discuss biology-teaching contexts and aim to inform readers about teaching strategies and innovations in biology education (Dolan, 2007). The American Biology Teacher, Advances in Physiology Education, and the Journal of College Science Teaching publish both essays and practice articles. Applied and theoretical research articles aim to develop or test theories about how students learn biology, explore how social and cultural norms influence biology teaching and learning, and describe processes by which students develop into biologists (Dolan, 2007). CBELife Sciences Education, the Journal of Research in Science Teaching, and Science Education often publish this kind of applied and theoretical research. For a more comprehensive list of journals that publish BER and to become familiar with how to locate and decipher DBER work, see Dolan's (2007) essay, "Grappling with the Literature of Education Research and Practice."

4. Start a brown-bag lunch series or organize a student group for peers interested in DBER. Informal meetings among peers can serve as venues to discuss interesting articles, hear from DBER speakers, disseminate or gather information on opportunities within the field, and form professional networks. Furthermore, creating such a venue for students from diverse fields, including chemistry, education, geosciences, physics, and psychology, can enrich discussions and allow graduate students in biology and peers in other departments to consider a variety of disciplinary perspectives. Additionally, these groups often serve as valuable support systems-occasionally the people involved in these endeavors become future collaborators and colleagues.

5. Conduct informational interviews. Talking to faculty and postdocs who conduct BER can orient interested graduate students to the field of BER and address more specific questions. Graduate students can ask postdocs about their academic trajectories and goals for their careers as postdocs and beyond and faculty about goals for their research groups. Interested graduate students should not hesitate to reach out to other institutions to find resources and make connections that will help provide information about the field. For example, students could read abstracts of papers by individuals who presented at an education conference and contact these people. We encourage broad exploration of BER in order to evaluate whether this path is a good fit.

These activities are intended to help graduate students clarify their interests and career goals. They can help address questions like, Is this work exciting or inspiring? Is there an alignment between my interests and a career involving BER or the improvement of biology teaching and learning? Students should carefully consider whether a BER postdoctoral position will provide the skills needed to obtain and be successful in a desired job. If a BER postdoctoral position is the right path, we offer some advice for becoming a strong candidate for these positions below.

\section{Becoming a Strong Candidate for a BER Postdoctoral Position}

In some ways, the qualifications for a BER postdoctoral position are similar to those for a biology postdoctoral position. Both require strong organizational skills, such as the ability to manage data collection across multiple study sites and analyze large-scale data sets. Written and verbal communication skills enable investigators to share their ideas and acquire future funding. While the ability to work independently can help drive research productivity, many research projects involve large interdisciplinary teams, so investigators must also be able to work collaboratively. One of the most important factors in hiring any research postdoc, including a BER position, is prior research experience and the quality of resulting publications. When we have been in the position of hiring BER postdoctoral researchers, we strongly preferred candidates with at least one publication. This demonstrates that the candidate has experience with the writing and revision process and a commitment 
to completing a project. However, we placed equal value on publications in biology research and BER.

Strong endorsements by advisors and mentors are another common consideration in the hiring of any postdoctoral candidate. Letters of reference tailored to address desired DBER qualities are particularly valuable. Thus, talking frequently and openly with advisors and mentors about education-related career goals can help in the pursuit of a BER postdoctoral position. These discussions can serve to increase the awareness of both advisors and students about the qualities a successful DBER postdoc might possess. Additionally, these conversations may help inform advisors about how best to mentor BER-interested graduate students. For example, through conversations, advisors may begin to recognize important DBER-related opportunities for their graduate students, such as helping to design and assess a new course. This can increase students' access to the activities that will make them successful BER postdoctoral candidates.

Our experience as candidates for BER postdoctoral positions and advisors of BER postdocs indicates that a consistent and strong commitment to education is a distinct and highly important consideration in the hiring of BER postdocs. A commitment to education demonstrates that the applicant's longterm interests align with the nature of the position. While this can take many forms, it goes beyond simply serving as a teaching assistant in graduate school. One way to become more involved in education as a graduate student is to engage with a center for teaching and learning (CTL) on campus. CTLs provide many teaching-related professional development opportunities for graduate students, such as teaching workshops or teaching certificate programs. There are also opportunities to work or volunteer at CTLs as a graduate student. For example, some CTLs have peer-mentoring programs in which graduate teaching assistants provide professional development and mentoring for peers. Experience working within a CTL may be particularly valuable training for BER postdoctoral positions that involve introducing faculty to novel teaching strategies or helping faculty with course design. Other valuable education-related activities include regular participation in educational outreach activities or designing and teaching a course, either at the home institution or as an adjunct at another local institution. Designing and teaching a course may be particularly helpful if there is a teaching expectation in the postdoctoral position, because it provides firsthand experience with the challenges of teaching.

In addition to a commitment to education, possessing methodological skills within the discipline is desirable. The diversity of research that biology education researchers conduct necessitates the use of a variety of experimental methods. Studies may rely on quantitative (e.g., statistical analyses of achievement data or Likert-type scale survey responses; for examples, see Haak et al., 2011; Aikens et al., 2016) or qualitative (e.g., open coding of verbal responses to interview questions or written responses to open-ended questions; for examples, see Shortlidge et al., 2016; Zagallo et al., 2016) methods, or they may use both in a mixed-methods approach. Taking courses outside of life science departments can help build skills in quantitative or qualitative research methods. Education, psychology, and social science departments often offer introductory courses on the research methods commonly used in DBER. These departments also offer higher-level courses on qualitative research, experimental design, and statistical analysis. Within life science disciplines, statistical courses in ecology, bioinformatics, or quantitative genetics are likely to offer quantitative training that can be applied to educational data. Training in structural equation modeling (e.g., Estrada et al., 2011) and generalized linear models, including mixed-effects models (e.g., Eddy et al., 2014), is particularly useful to address the quasi-experimental designs common in education studies. If engaging in education research or a course assessment project, take advantage of on-campus statistical and experimental design consulting services that can provide guidance and instruction in new research methods. While it is not necessary to master all the skills needed to conduct DBER before applying for a postdoctoral position, the strongest candidates will have a methodological background that demonstrates their motivation and ability to learn these skills independently.

Because a BER postdoctoral position revolves around research, it is critical to be familiar with current studies and topics of interest in BER. Fortunately, many of the activities we suggested in the preceding section, Deciding Whether a BER Postdoctoral Position Is the Right Career Move, would allow graduate students to assess their fit with the field while also becoming familiar with BER. Candidates should be familiar with some of the major questions in BER and be able to discuss a biology education problem of interest. Thus, it is critical for BER postdoctoral applicants to actively engage with the BER community through reading the literature, interacting with BER scholars, and thinking deeply about their own interests.

Conducting a small education research project is an ideal way to demonstrate the ability to transfer methodological training and knowledge of the BER literature to education research. For example, one author (S.L.E.) developed a new lab for an introductory biology series as a graduate student and conducted a pre/post assessment to demonstrate what students learned. She described this experience in her postdoctoral application, including what she learned about designing educational experiments and the experiment's shortcomings. This demonstrated her ability to critically think through an education experiment. Another author (G.T.) participated in the FIRST IV program (Ebert-May et al., 2015; Derting et al., 2016) during her first postdoctoral experience, which was a biology postdoctoral position. Working with colleagues in this program, she helped design an active-learning introductory biology course for a tribal college that included a final project in which students researched a scientific issue relevant to their community (Raines et al., 2013, 2014). When applying for BER postdoctoral positions, this project provided evidence of her familiarity with the education research process.

When we have been in the position of hiring BER postdocs, we considered the strongest candidates to be those with some experience conducting education research. Indeed, education research experience will become more critical in the coming years, as increasing numbers of BER graduate students, who will be trained in both biology and education research, enter the job market. While BER faculty are generally interested in providing mentorship and improving mentees' skills, they are also interested in making progress on research, and they may assume that a candidate with education research experience will be more productive. Thus, we strongly encourage candidates to take opportunities to work with faculty or other 
graduate students and to design and assess their own course components. However, for some candidates, this experience may be hard to obtain. For these students, we recommend thinking creatively about how to demonstrate BER potential through successful biology research, methodological skill development, and strong continuous involvement in biology education activities and the BER community.

Building a diverse network of supportive and knowledgeable people is valuable for the postdoctoral job search and beyond. Most of us found that a personal connection provided a valuable teaching or professional development opportunity, an introduction to BER researchers, or resources used to develop our interests. Making others aware of interests and intentions can be instrumental in gaining access to the support and skills needed to transition from biology to BER. Networking specifically with people in the education community, such as BER faculty or directors of CTLs, can also serve as an important source of job information. We recommend reaching out directly to editorial board members of journals that publish BER and authors of abstracts or articles of interest. The BER community is open, friendly, and eager to help the next generation of BER researchers. Do not hesitate to use this community as a resource.

In addition to networking, candidates can also find job announcements on the SABER website and the SABER and NARST listservs. Because teaching postdoctoral positions and BER postdoctoral positions may have similar titles, it is important to carefully read through a job announcement to understand the expectations for the position. This is also critical to ensure that the position aligns with long-term career goals. Do not hesitate to contact the faculty advisor to ask questions about the position. This may be particularly useful if there is interest in developing a specific skill (e.g., qualitative research experience or experience in faculty development) during the postdoctoral experience. Many BER faculty advisors recognize the diverse types of positions that BER postdocs pursue and accommodate opportunities that provide the postdoc with experience for a particular career. For example, if teaching experience is desired but is not an explicit part of a BER postdoctoral position, the faculty advisor may support and encourage the postdoc to find additional teaching opportunities. Contacting the faculty advisor can help to clarify the extent to which there is flexibility in the postdoc's activities.

\section{Other Paths to BER Postdoctoral Positions}

This article aims to provide advice primarily for graduate students conducting biology research; yet there are several other paths that may lead to postdoctoral positions in BER. For example, education graduate students studying STEM education for their dissertations may wish to pursue BER postdoctoral positions. Additionally, as more discipline-based education researchers are hired into life science departments, BER graduate programs will increase in number. These programs train students in both biology and education, though the structure of these programs varies from institution to institution. Thus, those seeking to employ BER postdocs have several applicant pools from which to draw. This is exciting, as BER labs will increasingly have members with highly diverse training and skill sets. Indeed, each of these paths has unique advantages and challenges and an essay such as this could be written for each. While it is beyond the scope of this paper, we hope that future essays might better address the various paths to careers in BER, highlight their advantages, and provide guidance on how to leverage the experiences from these different pathways into success. We also hope that readers of this paper, especially those early on in their education, will carefully consider the various paths forward and tailor their education to their goals. After all, it is best to move forward with the end in mind (Wiggins and McTighe, 2005).

\section{CONCLUSIONS}

It is an exciting time for the field of discipline-based BER. Although relatively new, the field is growing rapidly, and as such, the number of biology education-focused postdoctoral positions has increased over the years. For example, in 2014 through 2015, there were $\sim 46$ such postdoctoral positions advertised on the "jobs" portion of the SABER website, more than double the postings listed in 2011 through 2012. Of the 26 job postings made between June 2015 and June 2016, 14 were postdoctoral positions, and the majority of the remaining postings listed biology education postdoctoral training as a necessary or desired qualification. Many research and comprehensive universities have recently hired, or will be hiring, tenure-track faculty in biology education, thus increasing research opportunities in biology education for both graduate students and postdocs. For graduate students early in their careers, this could translate into opportunities to collaborate with biology education faculty on a side project or even on a chapter for their dissertations. For those on the brink of taking the next step in their academic careers, this opens the door to more varied postdoctoral options and a greater variety of ways in which new biology graduates can contribute to their discipline.

We end by reiterating the importance of aligning a postdoctoral position with long-term career goals. It is important to decide, first, whether a postdoctoral position in general is an appropriate career move, and second, whether a move to studying biology education fits with career goals. As with any postdoctoral position, a sincere interest in the research questions being addressed and a clear connection between the position and a future career goal will help to make it a rewarding experience.

\section{ACKNOWLEDGMENTS}

We thank the faculty who discussed their experiences and provided advice for this paper. We also thank Erin Dolan for thoughtful comments on a draft of the article and two anonymous reviewers for their helpful comments.

\section{REFERENCES}

Adams WK, Wieman CE (2011). Development and validation of instruments to measure learning of expert-like thinking. Int J Sci Educ 33, 1289-1312.

Aikens ML, Sadselia S, Watkins K, Evans M, Eby LT, Dolan EL (2016). A social capital perspective on the mentoring of undergraduate life science researchers: an empirical study of undergraduate-postgraduate-faculty triads. CBE Life Sci Educ 15, ar16.

Anderson DL, Fisher KM, Norman GJ (2002). Development and evaluation of the Conceptual Inventory of Natural Selection. J Res Sci Teach 39 952-978.

Angelo TA, Cross KP (1993). Classroom Assessment Techniques: A Handbook for College Teachers, San Francisco, CA: Jossey-Bass. 
Corwin LA, Runyon C, Robinson A, Dolan EL (2015). The Laboratory Course Assessment Survey: a tool to measure three dimensions of researchcourse design. CBE Life Sci Educ 14, ar37.

Couch BA, Wood WB, Knight JK (2015). The Molecular Biology Capstone Assessment: a concept assessment for upper-division molecular biology students. CBE Life Sci Educ 14, ar10.

Creswell JW (2014). Educational Research: Planning, Conducting, and Evaluating Quantitative and Qualitative Research, 5th ed., Boston, MA: Pearson.

Dasgupta AP, Anderson TR, Pelaez N (2014). Development and validation of a rubric for diagnosing students' experimental design knowledge and difficulties. CBE Life Sci Educ 13, 265-284.

D'Avanzo C (2008). Biology concept inventories: overview, status, and next steps. BioScience 58, 1079-1085

Derting TL, Ebert-May D, Henkel TP, Middlemis Maher J, Arnold B, Passmore HA (2016). Assessing faculty professional development in STEM higher education: sustainability of outcomes. Sci Adv 2, e1501422.

Dolan EL (2007). Grappling with the literature of education research and practice. CBE Life Sci Educ 6, 289-296.

Ebert-May D, Derting TL, Henkel TP, Middlemis Maher J, Momsen JL, Arnold B, Passmore HA (2015). Breaking the cycle: future faculty begin teaching with learner-centered strategies after professional development. CBE Life Sci Educ 14, ar22.

Eddy SL, Brownell SE, Wenderoth MP (2014). Gender gaps in achievement and participation in multiple introductory biology classrooms. CBE Life Sci Educ 13, 478-492.

Eddy SL, Converse M, Wenderoth MP (2015). PORTAAL: a classroom observation tool assessing evidence-based teaching practices for active learning in large science, technology, engineering, and mathematics classes CBE Life Sci Educ 14, ar23.

Estrada M, Woodcock A, Hernandez P, Schultz PW (2011). Toward a model of social influence that explains minority student integration into the scientific community. J Educ Psychol 103, 206-222.

Glynn SM, Brickman P, Armstrong N, Taasoobshirazi G (2011). Science motivation questionnaire II: validation with science majors and nonscience majors. J Res Sci Teach 48, 1159-1176.

Guinnee M (2006, 12 May). Postdoctoral teaching: savvy career move or distraction from research? ScienceCareers.

Haak DC, HilleRisLambers J, Pitre E, Freeman S (2011). Increased structure and active learning reduce the achievement gap in introductory biology. Science 332, 1213-1216.

Hanauer DI, Dolan EL (2014). The Project Ownership Survey: measuring differences in scientific inquiry experiences. CBE Life Sci Educ 13, 149-158.

Hoskins SG, Stevens LM, Nehm RH (2007). Selective use of the primary literature transforms the classroom into a virtual laboratory. Genetics 176 1381-1389.

Jensen JL, Kummer TA, Godoy PDDM (2015). Improvements from a flipped classroom may simply be the fruits of active learning. CBE Life Sci Educ $14, \operatorname{ar} 5$.

Kalinowski ST, Leonard MJ, Andrews TM, Litt AR (2013). Six classroom exercises to teach natural selection to undergraduate biology students. CBE Life Sci Educ 12, 483-793.

Knight JK (2010). Biology concept assessment tools: design and use. Microbiol Aust 31, 5-8.

Kreeger K (2002). At last, a chance for postdocs to learn how to teach. Nature 415,5
Lemons P (2001, 5 October). Teaching postdocs: an alternative approach to an academic career. ScienceCareers.

McDonnell L, Barker MK, Wieman C (2016). Concepts first, jargon second improves student articulation of understanding. Biochem Mol Bio Educ 44, 12-19.

National Research Council (2000). How People Learn: Brain, Mind, Experience, and School, exp ed., Washington, DC: National Academies Press.

Pellegrino JW, Chudowsky N, Glaser R (2001). Knowing What Students Know: The Science and Design of Educational Assessment, Washington, DC: National Academies Press.

Price M (2012, 26 October). Teaching postdocs to be professors. ScienceCareers.

Price RM, Andrews TC, McElhinny TL, Mead LS, Abraham JK, Thanukos A, Perez KE (2014). The Genetic Drift Inventory: a tool for measuring what advanced undergraduates have mastered about genetic drift. CBE Life Sci Educ 13, 65-75

Raines SM, George O, Torres S, Trujillo G (2014). Active science learning at SIPI (part II). Tribal Coll J Am Indian Higher Educ. www.tribalcollegejournal .org/archives/28029/print (accessed 16 June 2016).

Raines SM, George O, Torres S, Trujillo G, De Haro L (2013). Active science learning at SIPI. Tribal Coll J Am Indian Higher Educ. www.tribalcollegejournal .org/archives/26302/print (accessed 16 June 2016).

Schneider B, Carnoy M, Kilpatrick J, Schmidt WH, Shavelson RJ (2007). Estimating Causal Effects Using Experimental and Observational Designs. Washington, DC: American Educational Research Association.

Shavelson RJ, Towne L (2002). Scientific Research in Education, Washington, DC: National Academies Press.

Shortlidge EE, Bangera G, Brownell SE (2016). Faculty perspectives on developing and teaching course-based undergraduate research experiences. BioScience 66, 54-62.

Singer SR, Nielsen NR, Schweingruber HA (2012). Discipline-Based Education Research: Understanding and Improving Learning in Undergraduate Science and Engineering, Washington, DC: National Academies Press.

Slater SJ, Slater TF, Heyer I, Bailey JM (2015). Discipline-Based Education Research: A Guide for Scientists, Laramie, WY: Pono.

Smith MK, Jones FH, Gilbert SL, Wieman CE (2013). The Classroom Observation Protocol for Undergraduate STEM (COPUS): a new instrument to characterize university STEM classroom practices. CBE Life Sci Educ 12, 618-627.

Tanner K, Allen D (2004). Approaches to biology teaching and learning: learning styles and the problem of instructional selection-engaging all students in science courses. Cell Biol Educ 3, 197-201.

Thiry H, Laursen SL (2011). The role of student-advisor interactions in apprenticing undergraduate researchers into a scientific community of practice. J Sci Educ Technol 20, 771-784.

Weimer M (2006). Enhancing Scholarly Work on Teaching and Learning: Professional Literature That Makes a Difference, Indianapolis, IN: JosseyBass.

Wiggins G, McTighe J (2005). Understanding by Design, Alexandria, VA: Association for Supervision and Curriculum Development.

Zagallo P, Meddleton S, Bolger MS (2016). Teaching real data interpretation with models (TRIM): analysis of student dialogue in a largeenrollment cell and developmental biology course. CBE Life Sci Educ 15, ar17. 